\title{
Effects of Carbon and Oxygen on Fe-C-0 Melt Surface Tension
}

\author{
Keisuke MOROHOSHI, ${ }^{1,2)}$ Masahito UCHIKOSHI, ${ }^{1)}$ Minoru ISSHIKI ${ }^{1)}$ and Hiroyuki FUKUYAMA ${ }^{1) *}$ \\ 1) Institute of Multidisciplinary Research for Advanced Material (IMRAM), Tohoku University, Sendai, 980-8577 Japan. \\ 2) Research Fellow of Japan Society for the Promotion of Science.
}

(Received on February 18, 2013; accepted on April 30, 2013)

\begin{abstract}
For this study, we measured surface tension of $\mathrm{Fe}-\mathrm{C}$ and $\mathrm{Fe}-\mathrm{C}-\mathrm{O}$ melts accurately under controlled carbon and oxygen activities using an oscillating droplet method with an electromagnetic levitator (EML). The results are summarized as follows. The carbon activity has no influence on the surface tension of Fe-C melt at temperatures of $1823-2023 \mathrm{~K}$ under oxygen partial pressure of $10^{-10} \mathrm{~Pa}$. For Fe-C-O melts, the carbon activity has no influence on the surface tension at a constant oxygen partial pressure of $10^{-7} \mathrm{~Pa}$ and temperatures of 1873-1973 K. It is noteworthy that oxygen activity is reduced by carbon in the melt because of the negative interaction between oxygen and carbon. Considering the interaction, the surface tension of the $\mathrm{Fe}-\mathrm{C}-\mathrm{O}$ melts was formulated as a function of carbon and oxygen concentrations and temperature.
\end{abstract}

KEY WORDS: surface tension; Fe-C-O melts; carbon activity; oxygen activity; oscillating droplet method; electromagnetic levitation; gas-liquid equilibrium.

\section{Introduction}

Recently, numerical simulations have been used widely to optimize steel processes such as refining, casting, and welding. Therefore, accurate thermophysical properties of molten steel are required for simulations. The surface tension of $\mathrm{Fe}-\mathrm{C}-\mathrm{O}$ melts is necessary to simulate Marangoni flow in molten steel. We previously measured the surface tension of $\mathrm{Fe}-\mathrm{O}$ melts under various oxygen activities and temperatures. ${ }^{1)}$ Results show that an oxygen atom acts as a strong surface-active element, and that the surface tension of $\mathrm{Fe}-$ $\mathrm{O}$ melts is reduced significantly by oxygen adsorption. We developed the surface tension of $\mathrm{Fe}-\mathrm{O}$ melt as a function of oxygen activity and temperature based on the Szyszkowski model. $^{2)}$

The next step is to clarify the effect of carbon on the surface tension of $\mathrm{Fe}-\mathrm{C}$ melts. Many data have been reported in relation to the surface tension of $\mathrm{Fe}-\mathrm{C}$ melts as Keene reviewed in 1988. ${ }^{3)}$ However, the effects of carbon on the surface tension have not been viewed with consensus yet among the investigators. Kawai et al. ${ }^{4)}$ reported that carbon acted as a surface-active element. Halden and Kingery, ${ }^{5)}$ and Monma and $\mathrm{Sudo}^{6}$ ) reported that carbon has no influence on the surface tension. In contrast, Jimbo and Cramb ${ }^{7)}$ reported the positive dependence of carbon on surface tension.

Considering that oxygen is a strong surface-active element, we believe that oxygen obscures the true behavior of surface tension of $\mathrm{Fe}-\mathrm{C}$ melt. Therefore, controlling the oxygen activity is a key issue in solving the discrepancy among these investigators previous reports for the $\mathrm{Fe}-\mathrm{C}$ system.

We found that oxygen partial pressure should be less than

* Corresponding author: E-mail: fukuyama@tagen.tohoku.ac.jp DOI: http://dx.doi.org/10.2355/isijinternational.53.1315
$10^{-10} \mathrm{~Pa}$ to remove its influence on the surface tension. ${ }^{1)}$ In this study, we first examined the effect of carbon on the surface tension of $\mathrm{Fe}-\mathrm{C}$ melts under oxygen partial pressures below $10^{-10} \mathrm{~Pa}$. Subsequently, the surface tension of $\mathrm{Fe}-\mathrm{C}-$ $\mathrm{O}$ melts was studied at a constant oxygen partial pressure. An oscillating droplet method was used to measure the surface tension with an electromagnetic levitator (EML). The carbon and oxygen activities were controlled using a $\mathrm{CO} / \mathrm{CO}_{2}$ gas-liquid equilibrium method. The $\mathrm{Fe}-\mathrm{C}$ samples were also prepared using an iron/graphite pre-melting method. Based on the results, we formulated the surface tension of the $\mathrm{Fe}-\mathrm{C}-\mathrm{O}$ melts.

\section{Experimental}

\subsection{Gas-liquid Equilibrium Method}

We controlled oxygen and carbon activities using $\mathrm{Ar}-\mathrm{He}-$ $\mathrm{CO}-\mathrm{CO}_{2}$ gas mixtures. The following equilibrium reactions exist in the gas mixtures.

$$
\begin{array}{r}
2 \mathrm{CO}(\mathrm{g})+\mathrm{O}_{2}(\mathrm{~g})=2 \mathrm{CO}_{2}(\mathrm{~g}) \\
\mathrm{C}(\mathrm{s})+\mathrm{CO}_{2}(\mathrm{~g})=2 \mathrm{CO}(\mathrm{g}) .
\end{array}
$$

Oxygen and carbon activities are controlled according to the following equilibrium relations:

$$
\begin{aligned}
\log a_{\mathrm{O}_{2}} & =2 \log \frac{a_{\mathrm{CO}_{2}}}{a_{\mathrm{CO}}}-\log K_{(1)} \\
\log a_{\mathrm{C}} & =\log \frac{a_{\mathrm{CO}}^{2}}{a_{\mathrm{CO}_{2}}}-\log K_{(2)}
\end{aligned}
$$

where $a_{\mathrm{O}_{2}}, a_{\mathrm{CO}}$ and $a_{\mathrm{CO}_{2}}$ respectively represent the activities of $\mathrm{O}_{2}, \mathrm{CO}$ and $\mathrm{CO}_{2}$ relative to $10^{5} \mathrm{~Pa}$. Furthermore, $a_{\mathrm{C}}$ is a carbon activity relative to pure graphite at $10^{5} \mathrm{~Pa} . K_{(i)}$ is the 
equilibrium constant of reaction $(i)$, and the values of $K_{(1)}$ and $K_{(2)}$ were determined using thermochemical data. ${ }^{8)}$ Flow rates of $\mathrm{Ar}, \mathrm{He}, \mathrm{CO}$, and $\mathrm{CO}_{2}$ gases were adjusted to obtain the intended $a_{\mathrm{O}_{2}}$ and $a_{\mathrm{C}}$. The calculated $a_{\mathrm{O}_{2}}$ and $a_{\mathrm{C}}$ were confirmed by quantitative chemical analysis of oxygen and carbon dissolved in the iron sample after quenching.

\subsection{Experimental Procedure}

Figure 1 shows an experimental setup of the EML facility used to measure the surface tension of $\mathrm{Fe}-\mathrm{C}-\mathrm{O}$ melts. The maximum power and frequency of the radio frequency generator of the EML were, respectively, $15 \mathrm{~kW}$ and 200 kHz. High-purity ( 99.9972 mass \%) iron was prepared using the purification process containing anion exchange separation and $\mathrm{Ar}-\mathrm{H}_{2}$ arc plasma melting. ${ }^{9)}$ High-purity iron was used as a sample to prevent any effect of minor elements. The chemical composition of the high-purity iron is presented in Table 1.

The sample of about $1.0 \mathrm{~g}$ was placed on a quartz sample holder and positioned in a levitation coil. The quartz tube was evacuated to the order of $10^{-2} \mathrm{~Pa}$ using a diaphragm pump and turbo molecular pump, and was filled with highpurity Ar gas (99.9999 vol.\%). The iron sample was initially levitated in an Ar gas atmosphere using the EML facility, and an $\mathrm{Ar}-\mathrm{He}-\mathrm{CO}-\mathrm{CO}_{2}$ gas mixture was alternatively introduced into the quartz tube to control oxygen and carbon activities. The $\mathrm{Fe}-\mathrm{C}$ samples were also prepared by melting iron with graphite under an $\mathrm{Ar}-5$ vol. $\% \mathrm{H}_{2}$ gas atmosphere in a $\mathrm{BN}$ crucible before surface tension measurements. For pre-melted $\mathrm{Fe}-\mathrm{C}$ samples, an $\mathrm{Ar}-\mathrm{He}-5$ vol.\% $\mathrm{H}_{2}$ gas was used for surface tension measurements. Here, these gases were purified using an $\mathrm{Mg}$-deoxidizer kept at $873 \mathrm{~K}$ before introduction into the quartz tube.

The sample temperature was measured using a mono-color pyrometer (wavelength, $0.9 \mu \mathrm{m}$; temperature resolution, 1 $\mathrm{K}$; sampling rate, $2 \mathrm{~Hz}$ ). The pyrometer was calibrated at the

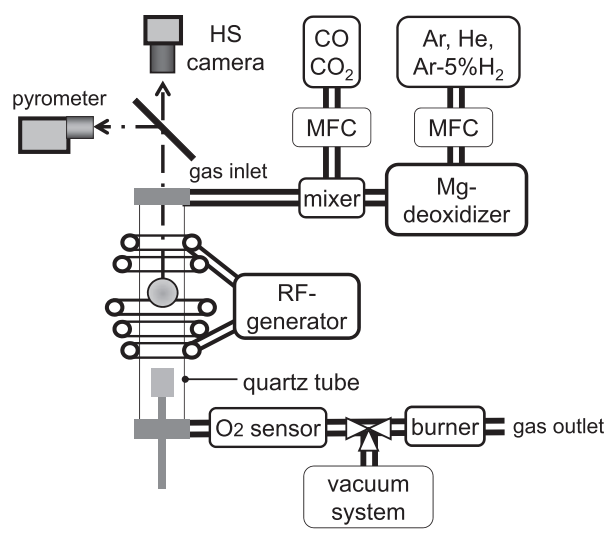

Fig. 1. Schematic diagram of an electromagnetic levitator to measure the surface tension of $\mathrm{Fe}-\mathrm{C}-\mathrm{O}$ melt with control of oxygen and carbon activities.

Table 1. Chemical composition of the high-purity iron (mass ppm).

\begin{tabular}{cccccccc}
\hline $\mathrm{Al}$ & $\mathrm{Si}$ & $\mathrm{P}$ & $\mathrm{S}$ & $\mathrm{Ti}$ & $\mathrm{Cr}$ & $\mathrm{Mn}$ & $\mathrm{Co}$ \\
\hline 0.19 & 0.17 & 0.20 & 0.15 & 0.59 & 0.011 & 0.049 & 1.6 \\
\hline $\mathrm{Ni}$ & $\mathrm{Cu}$ & $\mathrm{Se}$ & $\mathrm{Sr}$ & $\mathrm{Nb}$ & $\mathrm{Mo}$ & $\mathrm{Ag}$ & $\mathrm{Cd}$ \\
\hline 0.092 & 22 & 0.52 & 0.13 & 0.23 & 0.37 & 0.10 & 0.20 \\
\hline
\end{tabular}

melting temperature of iron $(1808 \mathrm{~K})$. The sample temperature was controlled by changing the He gas flow rate in the gas mixture. The images of the oscillating droplet were recorded using a high-speed camera with resolution of $512 \times$ 512 pixels at a frame rate of $250 \mathrm{fps}$ for $16 \mathrm{~s}$ from the sample top.

The gas-liquid equilibrium was confirmed by monitoring the surface tension variation with time. After recording the images, some samples were quenched, and were subjected to quantitative chemical analysis of oxygen and carbon in the sample to assure the gas-liquid equilibrium. Carbon and oxygen contents were analyzed using an infrared-absorption method with LECO TC-436 for oxygen analysis and LECO CS-444 LS for carbon analysis.

\subsection{Determination of Surface Tension}

The surface tension of the $\mathrm{Fe}-\mathrm{C}-\mathrm{O}$ melts was calculated from the following modified Rayleigh equation proposed by Cummings and Blackburn. ${ }^{10,11)}$

$$
\sigma=\frac{3 \pi M}{8}\left[\frac{1}{5} \sum_{m=-2}^{2} v_{m}^{2}-v_{t}^{2}\left\{1.9-1.2\left(\frac{g}{8 \pi^{2} v_{t}^{2} R_{0}}\right)^{2}\right]\right] \ldots
$$

Therein, $\sigma\left[\mathrm{N} \cdot \mathrm{m}^{-1}\right]$ denotes the surface tension, $M[\mathrm{~kg}]$ represents the sample mass, $v_{m}[\mathrm{~Hz}]$ is the surface oscillation frequency for $m=0, \pm 1$ and \pm 2 for the $l=2$ mode, $v_{t}[\mathrm{~Hz}]$ stands for the translation frequency of center of gravity, $g$ $\left[\mathrm{m} \cdot \mathrm{s}^{-2}\right]$ is the gravitational acceleration, and $R_{0}[\mathrm{~m}]$ is the sample radius. The values of $v_{m}$ and $v_{t}$ were determined through fast Fourier transformation (FFT) using the timesequential images of the oscillating droplet. The details of frequency analysis were explained with consideration of sample rotation in previous papers. ${ }^{1,12,13)}$ The value of $R_{0}$ was calculated using the density for the $\mathrm{Fe}-\mathrm{C}$ melt reported by Jimbo and Cramb, ${ }^{14)}$ which is given as

$$
\begin{aligned}
& \rho / \mathrm{kg} \cdot \mathrm{m}^{-3} \\
& =7100-73.2 w_{\mathrm{C}}-\left(0.828-0.0874 w_{\mathrm{C}}\right) \times(T-1823), \ldots
\end{aligned}
$$

where $\rho$ stands for the density, $T$ denotes the absolute temperature, and $w_{\mathrm{C}}$ signifies the carbon concentration in $\operatorname{mass} \%$ in the $\mathrm{Fe}-\mathrm{C}$ alloy.

\section{Results}

\subsection{Surface Tension of Fe-C Melts}

Figure 2 shows the surface tension of $\mathrm{Fe}-\mathrm{C}$ melts as a function of carbon concentration at $1873 \mathrm{~K}$ together with the previously reported values. ${ }^{4-7)}$ Figure 3 shows the surface tension as a function of $a_{\mathrm{C}}$. Table 2 shows details of date presented in Figs. 2 and 3. Here, the activity coefficient of carbon at $1873 \mathrm{~K}$ was evaluated from that at $1823 \mathrm{~K}^{15)}$ assuming a regular solution model, and was used for the activity-concentration conversion. In this study, all data were measured under $a_{\mathrm{O}_{2}}$ below $10^{-15}$ because the surface tension of liquid iron is sensitive to $a_{\mathrm{O}_{2}}$. It is necessary to control $a_{\mathrm{O}_{2}}$ below $10^{-15}$ to remove its effect. ${ }^{1)}$ The present result demonstrates that the surface tension of $\mathrm{Fe}-\mathrm{C}$ melts is independent of the carbon activity (carbon content). This is because that considering the positive deviation of $a_{\mathrm{C}}$ from Raoult's law, ${ }^{15)}$ carbon does not behave as a surface-active element for liquid iron. 


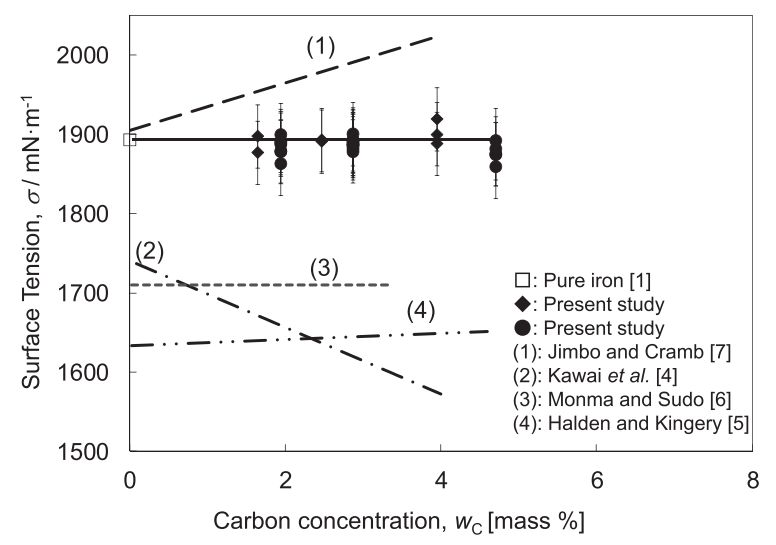

Fig. 2. Carbon concentration dependence of surface tension of $\mathrm{Fe}-$ C melt at $1873 \mathrm{~K}$.

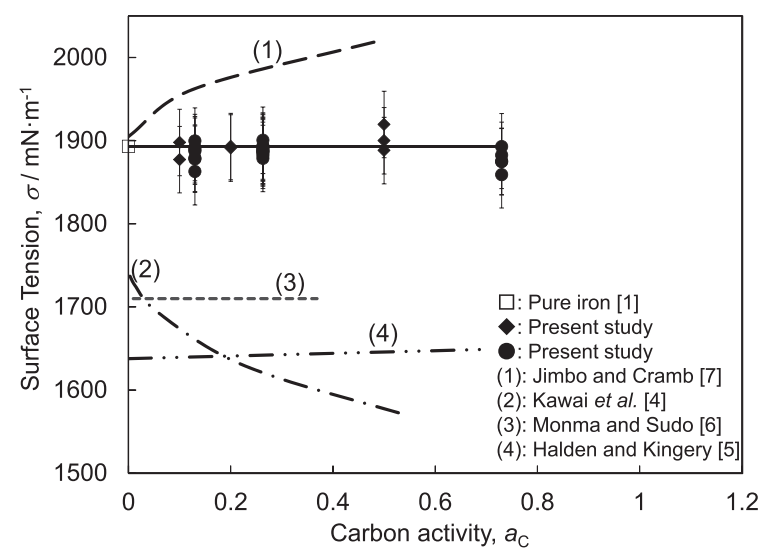

Fig. 3. Carbon activity dependence of surface tension of $\mathrm{Fe}-\mathrm{C}$ melt at $1873 \mathrm{~K}$, Symbols used in the figure are the same as those used in Fig. 2.

Table 2. Details of data presented in Figs. 2 and 3.

\begin{tabular}{|c|c|c|c|c|}
\hline Symbol & Investigators & Temp./K & $\begin{array}{l}\text { Method and Sample } \\
\text { preparation }\end{array}$ & Ref. \\
\hline$\square$ & Morohoshi et al. & 1873 & $\begin{array}{l}\mathrm{OD} \text { in } \mathrm{Ar}-\mathrm{He}-\mathrm{H}_{2}, \\
\text { pure iron }\end{array}$ & {$[1]$} \\
\hline$\diamond$ & Present study & 1873 & $\begin{array}{l}\mathrm{OD} \text { in } \mathrm{Ar}-\mathrm{He}-\mathrm{CO}-\mathrm{CO}_{2}, \\
\text { gas-lquid equilibrium }\end{array}$ & \\
\hline & Present study & 1873 & $\begin{array}{l}\mathrm{OD} \text { in } \mathrm{Ar}-\mathrm{He}-\mathrm{H}_{2}, \\
\text { iron/graphite pre-melting }\end{array}$ & \\
\hline (1) & Jimbo and Cramb & 1823 & $\begin{array}{l}\mathrm{SD} \text { in } \mathrm{CO}, \\
\text { iron/graphite pre-melting }\end{array}$ & {$[7]$} \\
\hline (2) & Kawai et al. & 1823 & $\begin{array}{l}\mathrm{SD} \text { in Ar, } \\
\text { iron/graphite pre-melting }\end{array}$ & {$[4]$} \\
\hline (3) & Monma and Sudo & 1873 & $\begin{array}{l}\mathrm{SD} \text { in } \mathrm{H}_{2} \text {, } \\
\text { iron/graphite pre-melting }\end{array}$ & {$[6]$} \\
\hline (4) & Halden and Kingery & 1843 & $\begin{array}{l}\mathrm{SD} \text { in } \mathrm{He} \text {, } \\
\text { iron/graphite pre-melting }\end{array}$ & {$[5]$} \\
\hline
\end{tabular}

OD, Oscillating droplet method; SD, Sessile drop method.

Jimbo and Cramb reported the positive dependence of carbon on the surface tension of $\mathrm{Fe}-\mathrm{C}$ melts as shown in Figs. 2 and 3. ${ }^{7)}$ They used a constant density data of liquid iron for surface tension calculation without considering effect of carbon on the density. Recalculation using Eq. (6) for the $\mathrm{Fe}-\mathrm{C}$ density reduced the carbon dependence, which agrees with the present data within their experimental uncertainty of $\pm 50 \mathrm{mN} \cdot \mathrm{m}^{-1}$. On the other hand, Kawai et al. ${ }^{2)}$

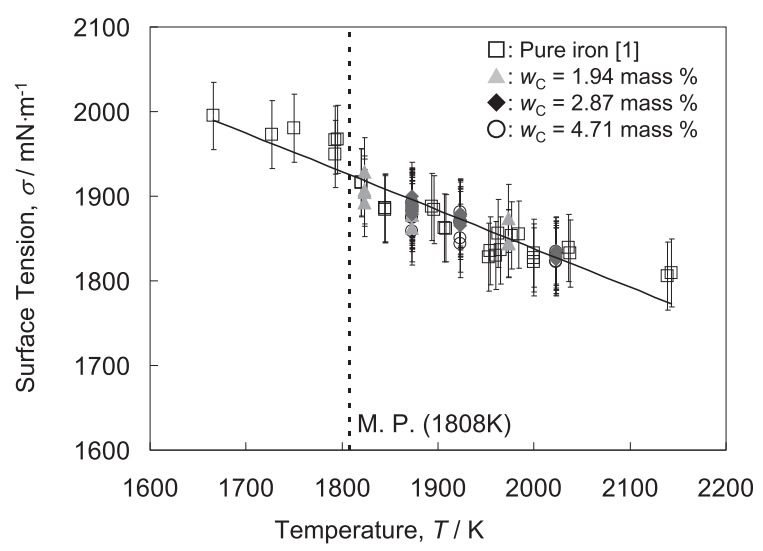

Fig. 4. Temperature dependence of surface tension of pure $\mathrm{Fe}$ and Fe-C melts.

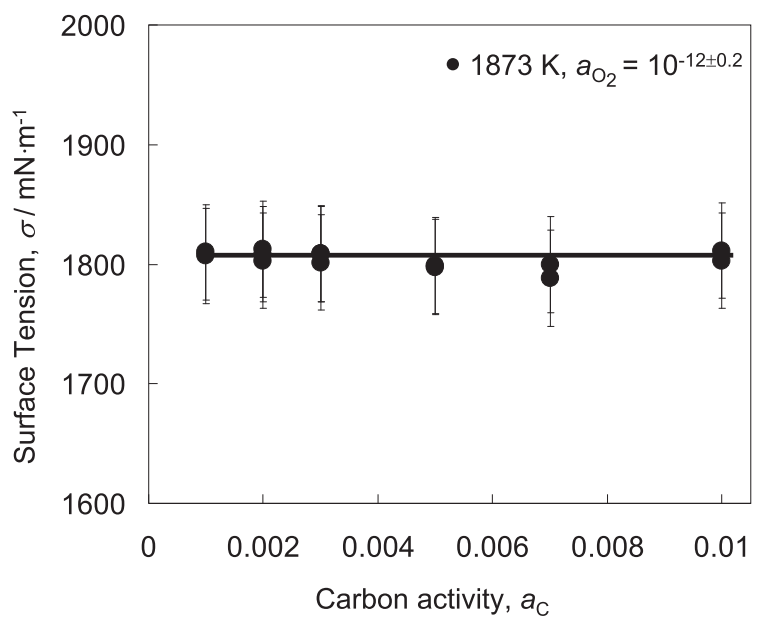

Fig. 5. Carbon activity dependence of surface tension of $\mathrm{Fe}-\mathrm{O}-\mathrm{C}$ melt at $a_{\mathrm{O}_{2}}=10^{-12}$ and $1873 \mathrm{~K}$.

reported the negative carbon-dependent value, and other previous data shows lower and carbon-independent values. ${ }^{3,4)}$ The reason for the different behaviors among the previous studies is not clearly understood yet. However, Jimbo and Cramb pointed out the effect of sulfur associated with carbon addition. ${ }^{7)}$ Sulfur is a strong surface-active element, and trace amounts of sulfur would cause the decrease in the surface tension.

Figure 4 shows the temperature dependence of surface tension of $\mathrm{Fe}-\mathrm{C}$ melts at high carbon concentration varying from 1.94 to 4.71 mass $\%$ together with that of pure liquid iron. ${ }^{1)}$ All the data present identical temperature dependence within experimental uncertainty.

\subsection{Surface Tension of $\mathrm{Fe}-\mathrm{C}-\mathrm{O}$ Melts}

Figure 5 presents the surface tension of $\mathrm{Fe}-\mathrm{C}-\mathrm{O}$ melts as a function of $a_{\mathrm{C}}$ at $1873 \mathrm{~K}$ at a constant $a_{\mathrm{O}_{2}}$ of $10^{-12}$ corresponding to an oxygen partial pressure of $10^{-7} \mathrm{~Pa}$. The surface tension was constant with $a_{\mathrm{C}}$. Figure 6 shows the temperature dependence of surface tension of $\mathrm{Fe}-\mathrm{C}-\mathrm{O}$ melts for two carbon activities $10^{-2}$ and $10^{-3}$ at $a_{\mathrm{O}_{2}}=10^{-12}$. The surface tension at $a_{\mathrm{O}_{2}}=10^{-12}$ was less than that of pure iron because of oxygen adsorption. However, it is readily apparent that solid squares $\left(a_{\mathrm{C}}=10^{-3}\right)$ and open diamonds $\left(a_{\mathrm{C}}=\right.$ $10^{-2}$ ) are located along the identical curve: the difference in carbon activity causes no difference in surface tension, even 


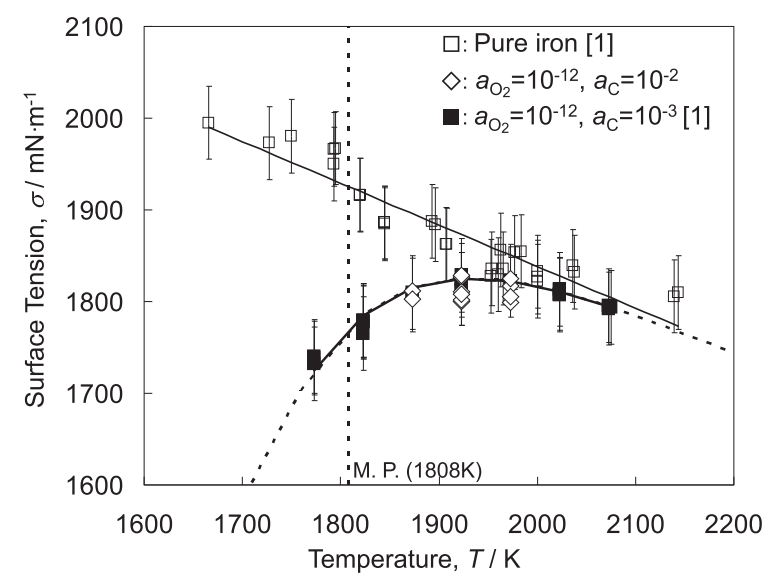

Fig. 6. Temperature dependence of surface tension of $\mathrm{Fe}-\mathrm{C}-\mathrm{O}$ melt measured under various carbon activities at $a_{\mathrm{O}_{2}}=10^{-12}$ compared to that of pure iron.

Table 3. Oxygen and carbon concentrations, $w_{\mathrm{O}}$ and $w_{\mathrm{C}}$, obtained from the chemical analysis. Comparison between $a_{\mathrm{O}_{2}}$ and $a_{\mathrm{C}}$ calculated from $\mathrm{CO}-\mathrm{CO}_{2}$ gas compositions and those calculated from the concentrations.

\begin{tabular}{|c|c|c|c|c|c|c|c|c|}
\hline \multicolumn{3}{|c|}{ Experimental condition } & \multicolumn{2}{|c|}{$\begin{array}{c}\text { Calculated } \\
\text { values using } \\
a_{\mathrm{CO}} \text { and } a_{\mathrm{CO}_{2}}\end{array}$} & \multicolumn{2}{|c|}{$\begin{array}{l}\text { Results of } \\
\text { chemical } \\
\text { analysis }\end{array}$} & \multicolumn{2}{|c|}{$\begin{array}{c}\text { Calculated } \\
\text { values using } \\
w_{\mathrm{O}} \text { and } w_{\mathrm{C}}\end{array}$} \\
\hline $\begin{array}{c}\text { Temp./ } \\
\text { K }\end{array}$ & $a_{\mathrm{CO}}$ & $a_{\mathrm{CO}_{2}}$ & $\log a_{\mathrm{O}_{2}}$ & $\log a_{\mathrm{C}}$ & $\begin{array}{c}w_{\mathrm{O}} \\
{[\mathrm{mass} \%]}\end{array}$ & $\begin{array}{c}w_{\mathrm{C}} \\
{[\mathrm{mass} \%]}\end{array}$ & $\log a_{\mathrm{O}_{2}}$ & $\log a_{\mathrm{C}}$ \\
\hline 1873 & $2.5 \times 10^{-}$ & $\times 10^{-6}$ & -16.0 & -0.3 & 0.0011 & 4.4 & -16.6 & -0.2 \\
\hline 1923 & $4.9 \times 10^{-1}$ & $1.1 \times 10^{-3}$ & -12.0 & -2.0 & 0.0022 & 0.26 & -12.3 & -2.0 \\
\hline 1973 & $3.4 \times 10^{-1}$ & $3.0 \times 10^{-4}$ & -12.0 & -2.0 & 0.0017 & 0.23 & -12.3 & -2.1 \\
\hline
\end{tabular}

at $a_{\mathrm{O}_{2}}=10^{-12}$.

Table 3 shows the oxygen and carbon concentrations, $w_{\mathrm{O}}$ and $w_{\mathrm{C}}$ (by mass\%) in the $\mathrm{Fe}-\mathrm{C}-\mathrm{O}$ samples obtained through the chemical analysis after the experiments conducted for different conditions. The values of $a_{\mathrm{O}_{2}}$ and $a_{\mathrm{C}}$ calculated from $w_{\mathrm{O}}$ and $w_{\mathrm{C}}$ agree with the values calculated from $\mathrm{CO}-\mathrm{CO}_{2}$ gas compositions used in the experiments, which means that the $a_{\mathrm{O}_{2}}$ and $a_{\mathrm{C}}$ were well controlled using the gas-liquid equilibrium method.

\section{Discussion}

\subsection{Modeling Surface Tension of Fe-C-O Melts}

This study revealed that carbon activity has no influence on the surface tension of $\mathrm{Fe}-\mathrm{C}-\mathrm{O}$ melts. Therefore, the effect of oxygen activity should be considered simply for estimation of the surface tension. We previously proposed the following expression to deduce the surface tension of Fe-O melts. ${ }^{1)}$

$$
\begin{aligned}
& \sigma / \mathrm{mN} \cdot \mathrm{m}^{-1} \\
& =(1925 \pm 65)-(0.455 \pm 0.034) \times(T-1808) \\
& -0.155 T \ln \left(1+\exp \left(\frac{(4.27 \pm 0.04) \times 10^{4}}{T}-(10.1 \pm 0.3)\right) a_{\mathrm{O}_{2}}^{1 / 2}\right)
\end{aligned}
$$

Using Eq. (7), the surface tension of $\mathrm{Fe}-\mathrm{C}-\mathrm{O}$ melts at 1873 $\mathrm{K}$ is evaluated as a function of oxygen and carbon activities

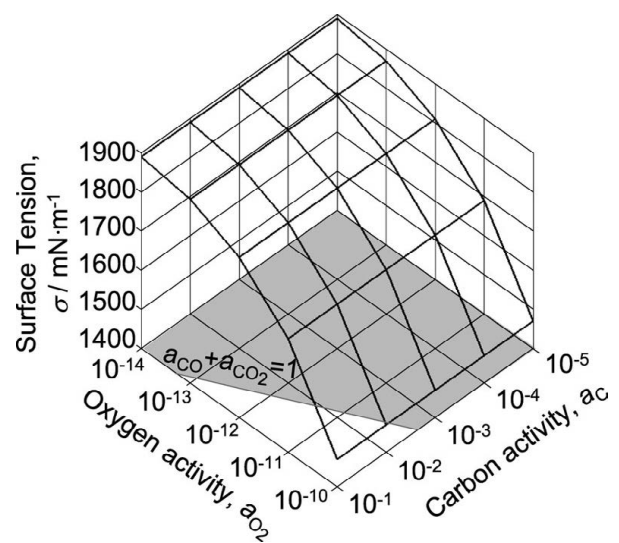

Fig. 7. Surface tension of $\mathrm{Fe}-\mathrm{C}-\mathrm{O}$ melts presented in the $\sigma-a_{\mathrm{C}}-a_{\mathrm{O}_{2}}$ $3 \mathrm{D}$ diagram at $1873 \mathrm{~K}$. The gray area shows where oxygen and carbon concentrations are controlled using the gas-liquid equilibrium method.

as portrayed in Fig. 7. The surface tension for each carbon activity is presented with identical parallel curves because the carbon effect was negligible. The gray area in the figure represents conditions under which oxygen and carbon activities are controlled using the gas-liquid equilibrium method.

\subsection{Modeling Surface Tension of Fe-C-O Melts as a Function of Oxygen and Carbon Concentrations}

To express Eq. (7) as a function of oxygen and carbon concentrations, the interaction between carbon and oxygen in molten iron should be regarded as follows. The dissolution reaction of oxygen in liquid iron is expressed as

$$
\frac{1}{2} \mathrm{O}_{2}(\mathrm{~g})=\underline{\mathrm{O}}(\text { in } \mathrm{Fe})
$$

where $\underline{\mathrm{O}}$ represents an oxygen atom dissolved in liquid iron. The equilibrium constant of Eq. (8) $K_{(8)}$ is presented as

$$
K_{(8)}=\frac{h_{\mathrm{O}}}{a_{\mathrm{O}_{2}}^{1 / 2}}=\exp \left(\frac{1.34 \times 10^{4}}{T}+0.8\right),
$$

where $h_{\mathrm{O}}$ is the oxygen activity relative to 1 mass $\%$ of oxygen in liquid iron based on Henry's law. The value of $K_{(8)}$ was determined using the standard Gibbs energy of the reaction: $\underline{\mathrm{O}}+\mathrm{H}_{2}=\mathrm{H}_{2} \mathrm{O}^{16)}$ and the standard Gibbs energy of formation of $\mathrm{H}_{2} \mathrm{O}(\mathrm{g}){ }^{8)}$ ) The value of $h_{\mathrm{O}}$ is defined using the activity coefficient $f_{\mathrm{O}}$ and oxygen concentration in mass $\%$ $w_{\mathrm{O}}$.

$$
h_{\mathrm{O}}=f_{\mathrm{O}} w_{\mathrm{O}}
$$

The $f_{0}$ is expressed using interaction parameters as

$$
\log f_{\mathrm{O}}=e_{\mathrm{O}}^{\mathrm{O}} w_{\mathrm{O}}+e_{\mathrm{O}}^{\mathrm{C}} w_{\mathrm{C}},
$$

where $e_{i}^{j}$ is an interaction parameter of $j$ for $i$. The following interaction parameters were used for this study. ${ }^{16)}$

$$
\begin{gathered}
e_{\mathrm{O}}^{\mathrm{O}}=-0.17 \\
e_{\mathrm{O}}^{\mathrm{C}}=-0.427
\end{gathered}
$$

These interaction parameters are applicable in the condition: $T=1823-1873 \mathrm{~K}, w_{\mathrm{C}} \leq 1 \mathrm{mass} \%$ and $w_{\mathrm{O}} \leq 0.21 \mathrm{mass} \%$. Substituting the equilibrium relation and interaction parameters Eqs. (9)-(13) into Eq. (7) produces Eq. (14) shown 


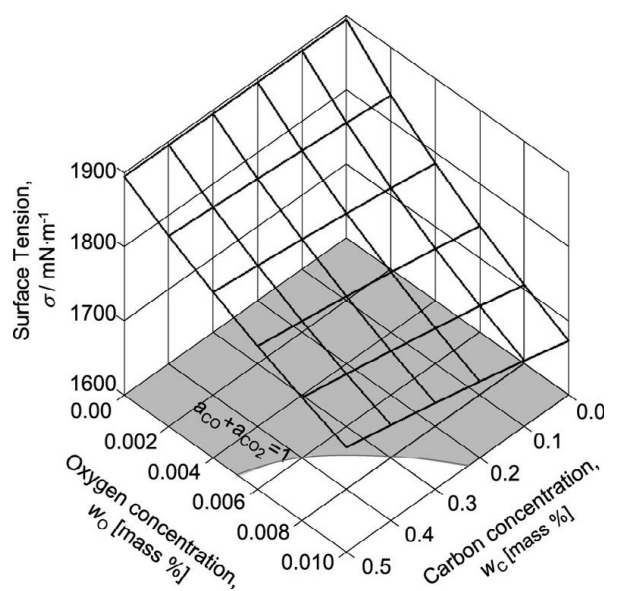

Fig. 8. Surface tension of $\mathrm{Fe}-\mathrm{C}-\mathrm{O}$ melts presented in the $\sigma-w_{\mathrm{C}}-w_{\mathrm{O}}$ $3 \mathrm{D}$ diagram at $1873 \mathrm{~K}$. The gray area shows where oxygen and carbon concentrations are controlled using the gas-liquid equilibrium method.

below.

$$
\begin{aligned}
& \sigma / \mathrm{mN} \cdot \mathrm{m}^{-1} \\
& =(1925 \pm 65)-(0.455 \pm 0.034) \times(T-1808) \\
& -0.155 T \ln \left(1+10^{-0.17 w_{\mathrm{O}}-0.427 w_{\mathrm{C}}} w_{\mathrm{O}} \exp \left(\frac{2.93 \times 10^{4}}{T}-10.9\right)\right)
\end{aligned}
$$

Using Eq. (14), the surface tension of $\mathrm{Fe}-\mathrm{C}-\mathrm{O}$ melts at $1873 \mathrm{~K}$ can be shown in the $\sigma-w_{\mathrm{O}}-w_{\mathrm{C}} 3 \mathrm{D}$ diagram as presented in Fig. 8. Comparing Figs. 8 to 7, carbon reduces oxygen activity in the melt, which eventually engenders increased surface tension. This is because of the negative interaction parameter between oxygen and carbon as presented in Eq. (13).

\section{Summary}

The surface tension of $\mathrm{Fe}-\mathrm{C}$ and $\mathrm{Fe}-\mathrm{C}-\mathrm{O}$ melts were measured using the oscillating droplet method with EML. The surface tension of $\mathrm{Fe}-\mathrm{C}$ melt is constant with carbon activities from $a_{\mathrm{C}}=0.1-0.73$ at temperatures of 1 823-2 023 $\mathrm{K}$ below $a_{\mathrm{O}_{2}}=10^{-15}$. The surface tension of $\mathrm{Fe}-\mathrm{C}-\mathrm{O}$ melts is also constant with carbon activities from $10^{-3}$ to $10^{-2}$ at $a_{\mathrm{O}_{2}}=10^{-12}$ at temperatures of $1873-1973 \mathrm{~K}$. The surface tension was formulated as a function of carbon and oxygen concentration and temperature considering the interaction between oxygen and carbon in the melts. Carbon itself has no influence on the surface tension. However, carbon reduces oxygen activity in the melt, which engenders an increase in the surface tension.

\section{Acknowledgments}

The authors thank Prof. T. Hibiya (Keio University) and Assoc. Prof. S. Ozawa (Chiba Institute of Technology) for their helpful comments and discussion. This work was financially supported by SENTAN, Japan Science and Technology Agency (JST) and ISIJ Research Promotion Grant. One author (KM) acknowledges support of a Grantin-Aid for JSPS Fellows.

\section{REFERENCES}

1) K. Morohoshi, M. Uchikoshi, M. Isshiki and H. Fukuyama: ISIJ Int., 51 (2011), 1580.

2) B. von Szyszkowski: Z. Phys. Chem., 64 (1908), 385.

3) B. J. Keene: Int. Mater. Rev., 33 (1988), 1.

4) Y. Kawai, K. Mori, M. Kishimoto, K. Ishikura and T. Shimoda: Tetsu-to-Hagané, $\mathbf{6 0}$ (1974), 29.

5) F. A. Halden and W. D. Kingery: J. Phys. Chem., 59 (1955), 557.

6) K. Monma and H. Sudo: J. Jpn. Inst. Met., 24 (1960), 167.

7) I. Jimbo and A. W. Cramb: ISIJ Int., 32 (1992), 26.

8) NIST-JANAF Thermochemical Tables, 4th ed., Part II Cr-Zr, ed. by M. W. Chase, Jr., American Chemical Society / American Institute of Physics, NY, (1998).

9) M. Uchikoshi, J. Imaizumi, H. Shibuya, T. Kékesi, K. Mimura and M. Isshiki: Thin Solid Film., 461 (2004), 94.

10) Lord Rayleigh: Proc. Royal Society, 29 (1879), 71.

11) D. L. Cummings and D. A. Blackburn: J. Fluid Mechanics, 224 (1991), 395.

12) K. Morohoshi, S. Ozawa, T. Tagawa and T. Hibiya: J. Jpn. Inst. Met, 72 (2008), 708.

13) S. Ozawa, T. Koda, M. Adachi, K. Morohoshi, M. Watanabe and T. Hibiya: J. Appl. Phys., 106 (2009), 034907.

14) I. Jimbo and A. W. Cramb: Metall. Mater. Trans. B, 24 (1993), 5.

15) T. Mori, K. Fujimura, H. Okajima and A. Yamauchi: Tetsu-toHagané, 54 (1968), 321.

16) Recommendation Equilibrium Values of Metallurgical Reaction, The 19th Committee of Steelmaking, JSPS, Tokyo, (1984). 